\title{
Pelletizing properties of torrefied spruce
}

Stelte, Wolfgang; Clemons, Craig; Holm, Jens K.; Sanadi, Anand R.; Ahrenfeldt, Jesper; Shang, Lei; Henriksen, Ulrik Birk

Published in:

Biomass \& Bioenergy

Link to article, DOI:

10.1016/j.biombioe.2011.09.025

Publication date:

2011

Link back to DTU Orbit

Citation (APA):

Stelte, W., Clemons, C., Holm, J. K., Sanadi, A. R., Ahrenfeldt, J., Shang, L., \& Henriksen, U. B. (2011). Pelletizing properties of torrefied spruce. Biomass \& Bioenergy, 35(11), 4690-4698.

https://doi.org/10.1016/j.biombioe.2011.09.025

\section{General rights}

Copyright and moral rights for the publications made accessible in the public portal are retained by the authors and/or other copyright owners and it is a condition of accessing publications that users recognise and abide by the legal requirements associated with these rights.

- Users may download and print one copy of any publication from the public portal for the purpose of private study or research.

- You may not further distribute the material or use it for any profit-making activity or commercial gain

- You may freely distribute the URL identifying the publication in the public portal

If you believe that this document breaches copyright please contact us providing details, and we will remove access to the work immediately and investigate your claim 


\section{Pelletizing properties of torrefied spruce}

Wolfgang Stelte $^{a *}$, Craig Clemons ${ }^{b}$, Jens K. Holm ${ }^{c}$, Anand R. Sanadi ${ }^{d}$, Jesper Ahrenfeldt $^{a}$, Lei Shang ${ }^{a}$ and Ulrik B. Henriksen ${ }^{a}$

${ }^{a}$ Biosystems Department, Risø National Laboratory for Sustainable Energy, Technical University of Denmark, Frederiksborgvej 399, DK-4000 Roskilde, Denmark.

${ }^{\mathrm{b}}$ Forest Products Laboratory, United States Department of Agriculture, 1 Gifford Pinchot Dr., Madison 53726-2398, WI, USA.

${ }^{\mathrm{c}}$ Chemical Engineering, DONG Energy Power A/S, A.C. Meyers Vænge 9, DK-2450, Copenhagen SV, Denmark.

${ }^{\mathrm{d}}$ Forest \& Landscape Denmark, Faculty of Life Sciences, University of Copenhagen, Rolighedsvej 23, DK-1985 Frederiksberg C, Denmark.

* Corresponding author. E-mail: stelte@gmail.com or wost@risoe.dtu.dk (W. Stelte); Tel.: +45 2132 5175; Fax: +45 46774109. 


\section{Abstract}

Torrefaction is a thermo-chemical conversion process improving the handling, storage and combustion properties of wood. To save storage space and transportation costs, it can be compressed into fuel pellets of high physical and energetic density. The resulting pellets are relatively resistant to moisture uptake, microbiological decay and easy to comminute into small particles. The present study focused on the pelletizing properties of spruce torrefied at 250,275 and $300{ }^{\circ} \mathrm{C}$. The changes in composition were characterized by infrared spectroscopy and chemical analysis. The pelletizing properties were determined using a single pellet press and pellet stability was determined by compression testing. The bonding mechanism in the pellets was studied by fracture surface analysis using scanning electron microscopy. The composition of the wood changed drastically under torrefaction, with hemicelluloses being most sensitive to thermal degradation. The chemical changes had a negative impact, both on the pelletizing process and the pellet properties. Torrefaction resulted in higher friction in the press channel of the pellet press and low compression strength of the pellets. Fracture surface analysis revealed a cohesive failure mechanism due to strong inter-particle bonding in spruce pellets as a resulting from a plastic flow of the amorphous wood polymers, forming solid polymer bridges between adjacent particles. Fracture surfaces of pellets made from torrefied spruce possessed gaps and voids between adjacent particles due to a spring back effect after pelletization. They showed no signs of inter-particle polymer bridges indicating that bonding is likely limited to Van der Waals forces and mechanical fiber interlocking.

\section{Introduction}

The utilization of wood and agricultural biomass residues for sustainable heat and power production is an important part of future energy concepts [1]. One of the major challenges of biomass utilization for heat and power production is its unfavorable handling properties. Biomass is a bulky and 
inhomogeneous material, making it both difficult and expensive to store and transport. Furthermore, it is difficult to comminute into small particles and has a relatively low energy density (compared to fossil fuels) and high moisture contents. An ancient process to improve the combustion properties of wood is the manufacturing of charcoal, resulting in a product that burns at higher temperature, is easier to ignite, and can be stored easier due to its better moisture resistance. Nevertheless, charcoal contains only 20-55 $\%$ of the raw material's energy content, depending on how well the process is carried out [2].

Torrefaction is an advance of this process, in which wood is roasted under controlled conditions (heating rate, temperature, time) in an inert atmosphere, retaining most of its energy [3]. The process results in an attractive fuel, with improved heating value, low moisture content and ease of size reduction [4]. Torrefaction is usually carried out between 230 to $300{ }^{\circ} \mathrm{C}$ [5] and removes moisture, carbon dioxide and volatiles from the biomass. Volatiles such as hydroxymethylfurfural, furfural and aldehydes are formed during the dehydration and decarboxylation reactions of the long polysaccharide chains [6]. The oxygen-to-carbon ratio is lowered significantly and the energy density of the biomass is increased, making it an ideal fuel for gasification processes where high oxygen contents are disadvantageous [7]. The value of torrefied biomass can be further improved by mechanical compression into pellets of high physical and energetic density [8]. The pelletization of biomass reduces its handling costs and results in a solid fuel of standardized shape and size that can be fed automatically in industrial and household size boilers being used for heat and power production. At present, there is a solid interest for utilizing torrefied wood pellets in existing large-scale combined heat and power (CHP) plants to replace coal with a biofuel without major changes in the power plant design [9].

The global production of fuel pellets from biomass was estimated to be about $13 \times 10^{9} \mathrm{~kg}$ in 2009 with strong growth rates, and it is expected that Europe alone will reach a consumption of 50 million tons per year by the year 2020 [10]. Consequently, the variety of raw materials used for pellet production has greatly increased in recent years and is expected to further increase in the future. The production of mixed biomass pellets produced from many different agricultural and forestry residues is increasing 
[11]. Biomass composition has a great effect on the pellet quality [12] and the pelletizing process itself [13].

Few studies have been published on using thermally pre-treated biomass in the pelletizing process $[14,15]$ but to the best of the authors knowledge none have so far studied in detail the impact of thermal degradation of the wood polymers on the pellet quality and integrity. In the present work, pellets were produced from Norway spruce and after torrefaction at 250,275 and $300{ }^{\circ} \mathrm{C}$. The chemical changes after torrefaction were investigated and their effect on the friction in the press channel of a pellet mill was studied using a laboratory scale single pellet press unit. The pellet stability was determined by compression testing and the internal bonding of the pellets was studied by fracture surface analysis using scanning electron microscopy (SEM).

\section{Experimental}

\subsection{Materials}

The raw material used in this study was Norway spruce (Picea abies K), harvested in southern Sweden (Skåne/Småland) during 2007. Wood stems were collected in autumn, debarked and comminuted into wood chips. The material was dried in a warehouse by free air circulation for four weeks and further chopped into particles $<5 \mathrm{~mm}$ in diameter using a hammer mill (Model 55, Jensen and Sommer Aps, Denmark). The material was packed in paper bags permeable to air and moisture and stored for 24 month in a dry storage. The used samples had a particle size between 1-2.8 $\mathrm{mm}$ and the mass fraction of water was about $8.2 \%$. 


\subsection{Torrefaction}

A lab scale torrefaction unit was constructed and built for this research similar to the one developed by Pimchuai et al. [5]. A metal box with a volume of about $2 \mathrm{~L}$ and two openings (5 $\mathrm{mm}$ in diameter) for nitrogen inlet and gas outlet was used as reactor. The box was installed in a programmable muffle furnace (S90, Lyngbyoven, Denmark) and connected to a nitrogen cylinder with pressure and flow regulator, water seal valve and fittings and pipes for gas inlet, outlet and temperature sensors. A temperature sensor (iron-constantan thermocouple) was installed in the center of the metal reactor and connected to a thermometer ( $52 \mathrm{KJ}$, John Fluke, USA) and a computer system controlling the heating of the oven. A torrefaction time of two hours and maximum temperature $\left(T_{\max }\right)$ of 250,275 and $300{ }^{\circ} \mathrm{C}$ have been chosen according to Pimchuai et al. [5].

About $450 \mathrm{~g}$ of wood particles were weighed in and sealed in the metal box. The box was put in the oven and heated at a rate of $2{ }^{\circ} \mathrm{C} \mathrm{min}^{-1}$ until $T_{\max }$ was reached and kept constant for 2 hours. Afterwards the oven was switched off and the samples were allowed to cool. Nitrogen was flushed through the box at a rate of $0.5 \mathrm{~L} \mathrm{~min}^{-1}$ until the samples were cooled to ambient conditions. Dry weight was determined before and after torrefaction and was used to calculate the mass loss. The torrefied samples were conditioned in climate chambers at $27^{\circ} \mathrm{C}$ at 65,80 or $90 \%$ relative humidity until a constant weight was reached. The samples were termed T250, T275 and T300 according to the $T_{\max }$ reached during torrefaction.

\subsection{Attenuated total reflectance infrared spectroscopy (ATR-FTIR)}

ATR-FTIR spectra of the pellet fracture surfaces were recorded at $30{ }^{\circ} \mathrm{C}$ using a Fourier transform infrared spectrometer (Nicolet 6700 FT-IR, Thermo Electron Corporation, USA), equipped with a temperature-adjustable ATR accessory (Smart Golden Gate diamond ATR accessory, Thermo Electron 
Corporation, USA). Samples were dried at $105{ }^{\circ} \mathrm{C}$ for 4 hours and stored in airtight containers until used for testing. A minimum of five measurements per sample was performed. To ensure good contact, all hard, solid samples were pressed against the diamond surface using a metal rod and consistent mechanical pressure. All spectra were obtained with 200 scans for the background (air), 100 scans for the sample and with a resolution of $4 \mathrm{~cm}^{-1}$ from $500-4000 \mathrm{~cm}^{-1}$. Spectra were normalized at around 760$790 \mathrm{~nm}$ where the spectra were free of any distinct IR bands.

\subsection{Biomass characterization}

A fiber analysis to study the biomass composition (cellulose, lignin, hemicelluloses and ash content) was conducted according to the procedure used by Davis et al. [16] and can be summarized as follows. About $10 \mathrm{~g}$ per sample were milled to pass through a screen with a mesh size of $0.84 \mathrm{~mm}$ and then vacuum-dried at $45^{\circ} \mathrm{C}$. Approximately $100 \mathrm{mg}$ sample were hydrolyzed in $1 \mathrm{~mL}$ sulfuric acid (13.5 mol $\mathrm{L}^{-1}$ ) for 1 hour at $30{ }^{\circ} \mathrm{C}$. The samples were diluted to a sulfuric acid concentration of $0.75 \mathrm{~mol} \mathrm{~L}^{-1}$ by adding distilled water. Fucose was added as an internal standard, and a secondary hydrolysis was performed for 1 hour at $121^{\circ} \mathrm{C}$. To control for sugar degradation during secondary hydrolysis, a standard mixture of sugars was hydrolyzed in parallel with each batch of samples. Material loss during primary hydrolysis was minimal and therefore ignored. The following secondary hydrolysis samples were immediately filtered through tared Gooch porcelain crucibles containing glass fiber filters (934$\mathrm{AH}$, Whatman, USA). The filtrate and three washes with $5 \mathrm{~mL}$ distilled water were collected in $100 \mathrm{~mL}$ volumetric flasks and brought to volume with water. The acid-insoluble residue (Klason lignin and insoluble degradation products) was washed for additional six times with $10 \mathrm{~mL}$ hot distilled water and its weight determined gravimetrically. Klason lignin values were corrected for ash content by gravimetric measurement following incubation of the lignin at $575{ }^{\circ} \mathrm{C}$ for $>3$ hours. Sugar contents of the hydrolysates were determined by anion exchange high performance liquid chromatography using 
pulsed amperometric detection. After filtration through $0.45 \mu \mathrm{m}$ PTFE membranes, acid hydrolysates (sulfuric acid concentrations ranging between $0.2-0.75 \mathrm{~mol} \mathrm{~L}^{-1}$ ) were injected with no further treatment. The chromatographic system consists of an autosampler (AS50, Dionex, USA) a quaternary gradient high pressure pump (GS50, Dionex, USA), and a pulsed amperometric detector (ED50, Dionex, USA). Sugar separation was achieved with guard and analytical columns (Carbo-Pac PA1, Dionex, USA) connected in series. Sugars were eluted with distilled water at a flow rate of $1.1 \mathrm{~mL} \mathrm{~min}^{-1}$ and a temperature of $18^{\circ} \mathrm{C}$. For detection, sodium hydroxide solution $\left(0.3 \mathrm{~mol} \mathrm{~L}^{-1}\right)$ as added as a post-column

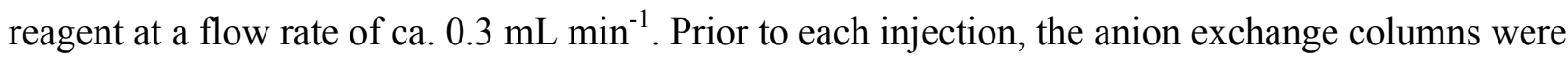
conditioned with $400 \mathrm{~mL}$ sodium acetate solutions $0.24 \mathrm{~mol} \mathrm{~L}^{-1}$ and then equilibrated with distilled water. Sugars were quantitated using an internal standard method. Results are reported in terms of percent of the original sample mass dry matter.

Moisture uptake was studied by spreading $5 \mathrm{~g}$ of each material on a tray and conditioning in climate chambers (USDA Forest products lab, USA) at $27{ }^{\circ} \mathrm{C}$ and a relative moisture content of 65,80 and 90 $\%$. Equilibrium moisture content was determined after the weight of the sample was constant for three days in a row. The moisture content was calculated based on weight loss after oven drying the material for 8 hours at $105^{\circ} \mathrm{C}$.

\subsection{Pellet preparation and determination of pelletizing pressure $P_{x}$ in the channel of the pellet press}

The pellets were prepared as described in [12], using a single pellet press (invented and constructed at the workshop of the Technical University of Denmark, Denmark). The press consisted of a cylindrical die $7.8 \mathrm{~mm}$ in diameter, made of hardened steel, lagged with heating elements and thermal insulation. The temperature was controlled using a thermocouple connected to a control unit. The end of the die was closed using a removable backstop. Pressure was applied using a metal piston. The entire pellet press was mounted in a material test system (MTS 810 Material Test system, MT Systems Corporation, 
USA) so that piston movement could be controlled and the force could be measured using a $100 \mathrm{kN}$ load cell. The die was rinsed with acetone, and wiped clean using a paper towel before each use, and when changing raw materials. To simulate the pelletizing process within a commercial pellet mill, the pellet had to be built up in sequential layers [17]. The die was heated to $100{ }^{\circ} \mathrm{C}$. Spruce and torrefied spruce particles equilibrated at $65 \%$ relative humidity (see Figure 3 for moisture content) were loaded stepwise in amounts less than $0.25 \mathrm{~g}$ into the unit, and then compressed at a rate of $2 \mathrm{~mm} \mathrm{~s}^{-1}$ until a maximum pressure of $200 \mathrm{MPa}$ was reached. The pressure was released after five seconds, the piston removed, and more biomass was loaded and compressed until the pellet had a length of about $16 \mathrm{~mm}$. This results in a layered structure, similar to pellets obtained by commercial units, although there are some differences. The most significant difference is that the lower part of the pellet is pressed repeatedly, and the upper layers are pressed fewer times, with the top layer being pressed only once. For determination of pelletizing pressure in the press channel of the pellet mill, $P_{x}$, the pellets were removed from the die by removing the backstop and pushing out the pellet at a rate of $2 \mathrm{~mm} \mathrm{~s}^{-1}$. The applied maximum force was logged and $P_{X}$ was calculated based on the pellet surface area.

\subsection{Determination of pellet strength}

The internal strength of the manufactured pellets was analyzed by compression testing and determined as the force at break. Pellets $16 \mathrm{~mm}( \pm 1 \mathrm{~mm})$ in length and between 7.9 and $8.2 \mathrm{~mm}$ in diameter were produced in the single pellet press, stored at a relative humidity of $50 \%$ and $20{ }^{\circ} \mathrm{C}$ for three weeks, and tested under the same conditions. The pellets were placed on their side (the pellet's cylindrical shape oriented horizontally) in the same material tester as was used for pellet preparation. Compression tests were performed using a disc shaped metal probe with a ball bearing of $50 \mathrm{~mm}$ in diameter and attached to a $100 \mathrm{kN}$ load cell. The test was run at a compression rate of $20 \mathrm{~mm} \mathrm{~min}^{-1}$ and was stopped after pellet failure. The average force at break and its standard deviation were calculated based on 5 
replications per test condition.

\subsection{Scanning electron microscopy (SEM)}

SEM was used to study the bonding mechanism of the prepared biomass pellets by fracture surface analysis of failed pellets. The compression test resulted in total disintegration of the pellets, and therefore fracture surfaces were prepared by manually breaking a pellet into two parts. Care was taken to replicate the way each pellet was broken and that it took place in the same region. A tiny notch was cut in the center of the pellet using a razor blade, and the pellets were snapped into two. Care was taken to examine the fracture surface away from the notch. The two halves of the fractured pellet were attached to metal stubs using a conductive silver paste (Conductive silver paste plus, SPI Supplies, USA) that was carefully applied below and around the sample to prevent electric charging of the specimen. The upper surface was coated with a thin layer of gold using a sputter coater (Desk-1 sputter coater, Denton, USA). Electron micrographs were recorded using a scanning electron microscope (LEO EVO 40 SEM, Carl Zeiss, Germany) operated at 5-15 kV. Multiple samples were observed for each type of pellet and representative images were selected for each sample type.

\subsection{Pellet density}

The obtained pellets were stored at $50 \%$ relative humidity at $20{ }^{\circ} \mathrm{C}$ for one month. The unit density of the pellets was calculated by determination of the pellets weight and dimensions for at least 5 samples for pellets pressed at each condition. 


\section{Results and Discussion}

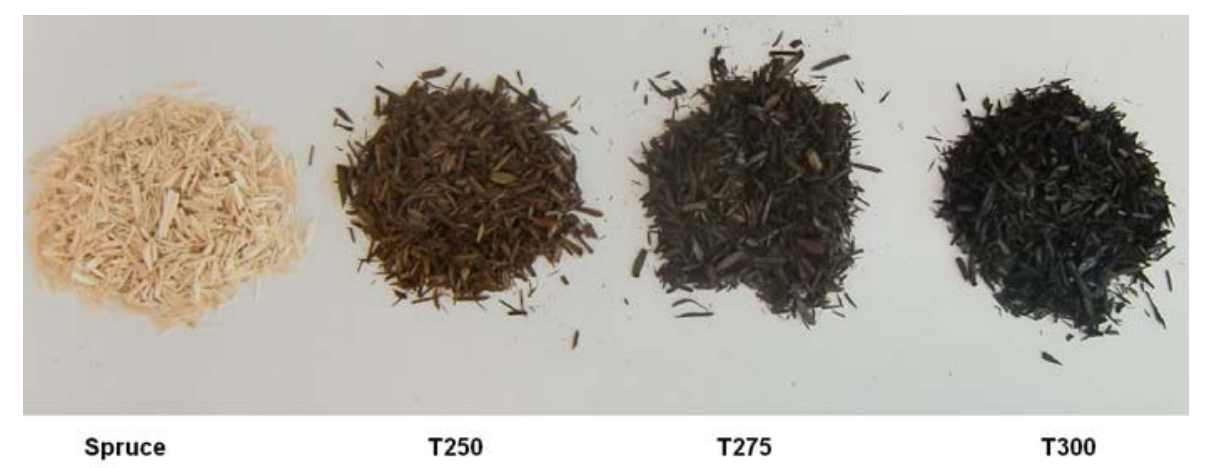

Figure 1. Color change during the torrefaction process.

The torrefaction of spruce at 250,275 and $300{ }^{\circ} \mathrm{C}$ resulted in three products of light brown, dark brown and black color as shown in Figure 1. The color change is mainly attributed to chemical changes of the lignin, i.e. the formation of chromaphoric groups, mainly the increase of carbonyl groups [18]. The loss of dry matter (anhydrous weight loss) through volatilization during torrefaction was $25 \%$ at $250{ }^{\circ} \mathrm{C}, 34$ $\%$ at $275{ }^{\circ} \mathrm{C}$ and $53 \%$ at $300{ }^{\circ} \mathrm{C}$.

Table 1. Composition of spruce and spruce torrefied at $250{ }^{\circ} \mathrm{C}(\mathrm{T} 250), 275{ }^{\circ} \mathrm{C}$ (T275) and $300{ }^{\circ} \mathrm{C}$ (T300) in percentage of total dry matter (average of two replicates).

\begin{tabular}{|c|c|c|c|c|}
\hline & Cellulose & Hemicellulose & Acid insoluble fraction & Ash \\
\hline Norway Spruce & 43.7 & 23.3 & $28.9 *$ & 0.1 \\
\hline T250 & 43.6 & 6.6 & 43.2 & 0.1 \\
\hline T275 & 32.7 & 0.7 & 62.2 & 0.3 \\
\hline T300 & 0.2 & 0.0 & 99.0 & 0.6 \\
\hline
\end{tabular}

*) In case of spruce the acid insoluble fraction is defined as Klasson lignin content 
The chemical analysis of the torrefied spruce shows a strong decrease of hemicellulose and cellulose content and is attributed to the thermal degradation of the carbohydrate polymers into volatile compounds and the evaporation of water and carbon dioxide [19]. Hemicelluloses are well known to undergo a two step thermal degradation where light volatiles i.e. mono and polysaccharides, followed by their catalytic degradation into $\mathrm{CO}$ and $\mathrm{CO}_{2}[20]$. Lignin undergoes depolymerisation, mainly $\beta$-arylether linkages and re-condensation reactions that lower its average molecular weight [6]. The relative increase in the acid-insoluble fraction with torrefaction temperature is likely due to both the volatilization of some of the carbohydrate fraction as well as the formation of acid-insoluble degradation products from them [21]. For example, cellulose can undergo scission reactions with aromatization and cross-linking, resulting in an insoluble solid [22]. The chemical changes occurring during torrefaction have been studied using ATR-FTIR-spectroscopy and the results are shown in Figure 2.

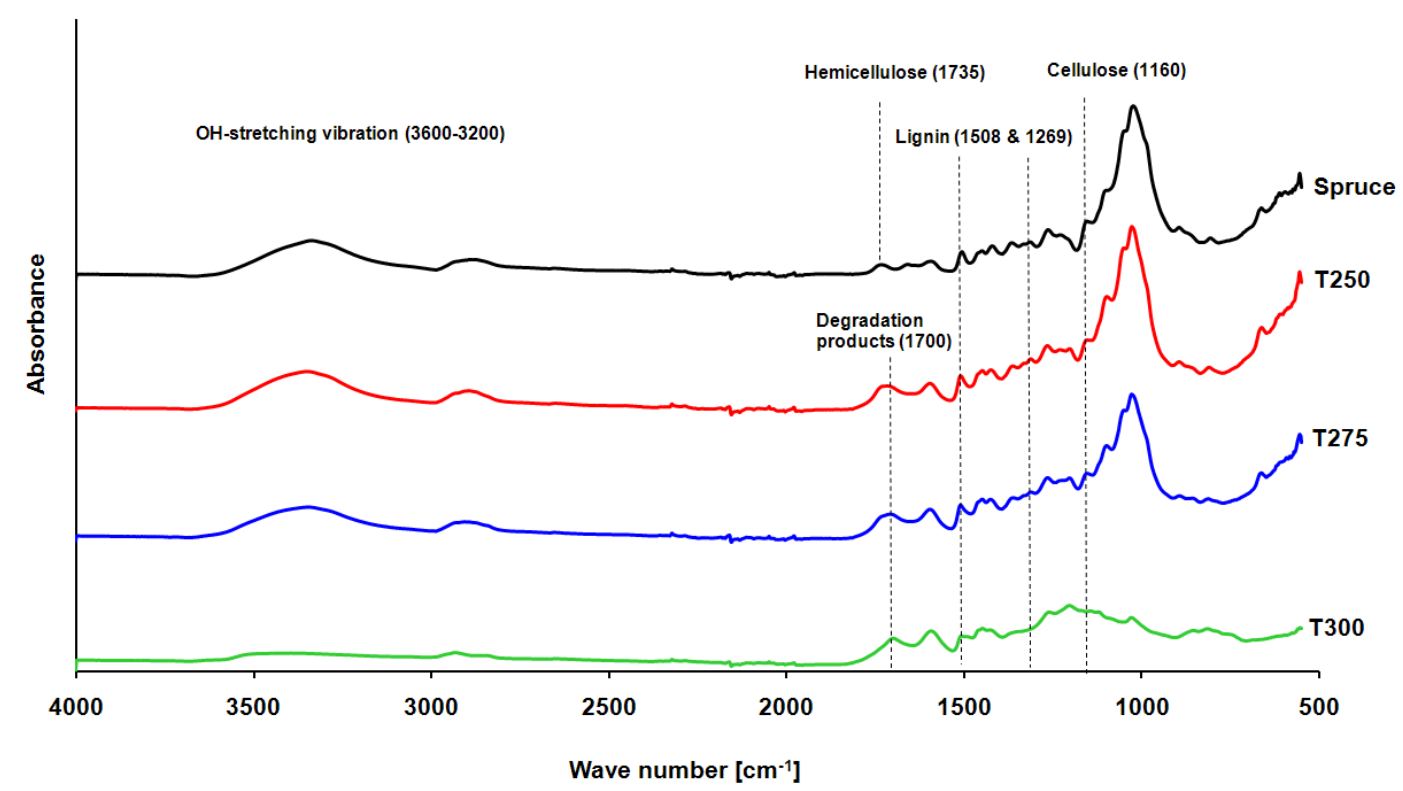

Figure 2. ATR-FTIR spectra of dry spruce and torrefied spruce at 250,275 and $300{ }^{\circ} \mathrm{C}$. For better comparability, the scale of the y-axis was adjusted. 
The IR spectra of spruce and torrefied spruce at 250 and $275^{\circ} \mathrm{C}$ have several features in common, while the spectra of spruce torrefied at $300{ }^{\circ} \mathrm{C}$ has very different characteristics. The broad band in the $\mathrm{OH}$ stretching vibration region at about $3600-3200 \mathrm{~cm}^{-1}$ is due to intra- and inter molecular hydrogen bonds and bands characteristic of crystalline cellulose [23-25]. The intensity of these bands decreases with increasing torrefaction temperature and has almost disappeared at $300{ }^{\circ} \mathrm{C}$. This indicates that the torrefied material contains less water and hydrogen bonding sites due to the degradation of hemicelluloses and cellulose, which is supported by the chemical analysis data (Table 1). A lignin vibration can be found at about $1269 \mathrm{~cm}^{-1}$ (the aromatic C-O stretching of methoxyl and phenyl propane units) and at $1516 \mathrm{~cm}^{-1}$ and $1508 \mathrm{~cm}^{-1}(\mathrm{C}=\mathrm{C}$ aromatic ring vibrations) $[23,26,27]$.These bands were present in the raw material and after treatment at 250 and $275^{\circ} \mathrm{C}$ at same intensity but has disappeared after treatment at $300{ }^{\circ} \mathrm{C}$, this suggests that the lignin, to large extent, has been degraded at this high temperature. Vibrations at about $1735 \mathrm{~cm}^{-1}$ are related to $\mathrm{C}=\mathrm{O}$ stretching vibrations of the carboxylic acids of hemicelluloses (i.e. xyloglucan, arabinoglucuronoxylan and galactoglucomannan) [23, 28]. This vibration is only present in the raw material. The torrefied samples show a band at about $1700 \mathrm{~cm}^{-1}$ which is attributed to a degradation product formed during the torrefaction. This indicates that hemicelluloses are degrading already at $250^{\circ} \mathrm{C}$, which agrees with the chemical analysis data (Table 1). The band at $1160 \mathrm{~cm}^{-1}$ is celluloses antisymmetric stretching of C-O-C glycosidic linkages [29] its intensity is strongest for untreated spruce and decreases with increasing torrefaction temperature. The band is not present at $300{ }^{\circ} \mathrm{C}$, which indicates that most cellulose has degraded at this temperature.

Torrefaction has been reported to have a strong effect on the mechanical stability and combustion properties of biomass $[2,3,4]$.

Since the IR data has shown that most of the hydrogen-bonding hydroxyl groups have been removed during torrefaction, the moisture uptake of torrefied biomass is expected to decrease. The results 
presented in Figure 3 show that the spruce absorbed twice as much water as it did after torrefaction at $250{ }^{\circ} \mathrm{C}$. The ability to absorb water decreased further after the 275 and $300{ }^{\circ} \mathrm{C}$ treatment.

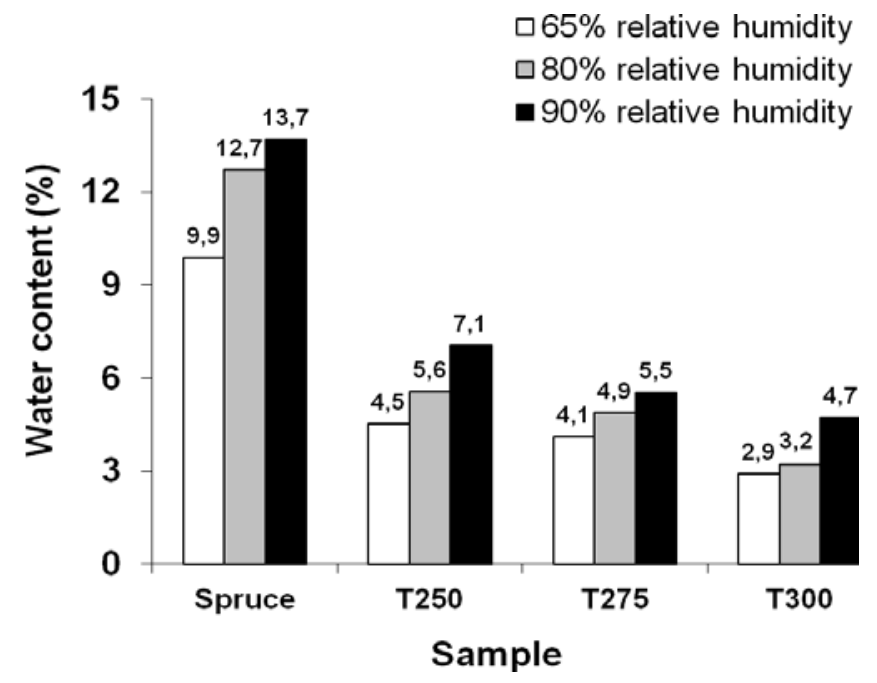

Figure 3. Moisture content of spruce and torrefied spruce after three weeks storage at $27^{\circ} \mathrm{C}$ and 65,80 and $90 \%$ relative humidity.

There are three different types of bound water in wood [30]. Non-freezing bound water is specifically bound to the hydroxyl groups of the wood polymers, especially the hemicelluloses. Freezing bound water is loosely bound to hydroxyl groups organized in clusters and can be found at high humidity in nanovoids and on the wall lining of macro- and microvoids. Free water is held in macro- and microvoids and bound by capillary forces but not to specific sorption sites. Since hemicelluloses are degraded during the heat treatment and most hydroxyl groups are removed, it is likely that water in torrefied wood is mainly bound as free water in macro- and micro-sized voids where it is held in place by capillary forces. This supports the observation, made during this study, that torrefied wood reaches equilibrium moisture content much faster than untreated wood.

The differences in composition and water content have also a strong effect on the pelletizing properties 
for spruce and the torrefied spruce. The pelletizing pressure in the press channel of the pellet mill $\left(P_{x}\right)$ is a crucial parameter in pelletizing processes in terms of process energy consumption and pellet quality $[15,31]$.

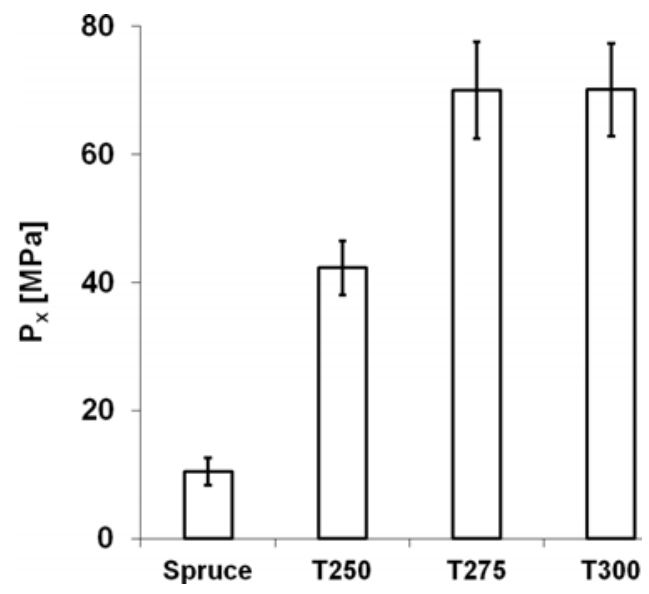

Figure 4. Pressure $\left(P_{x}\right)$ during the pelletization of spruce and torrefied spruce.

$P_{x}$ increases drastically when comparing spruce and torrefied spruce (Figure 4). This increase is most likely attributed to the lack of water and low hemicelluloses content in the torrefied spruce. Water acts as a plasticizer, lowering the softening temperature of the wood polymers. In nature, hemicelluloses bind lignin and cellulose fibrils and provides flexibility in the plant cell wall [32]. Their degradation embrittles wood, making it easier to comminute into small particles $[4,33]$. The degradation of the hemicelluloses, cellulose and the lignin are likely to affect important pelletizing parameters such as the friction coefficient and Poisson ratio which are directly correlated to $P_{x}[15]$.

It is likely that extractives are removed during the torrefaction process. Extractives have been shown to play an important role during the pelletizing process [12] and are likely to act as lubricant lowering the 
friction in the press channel.

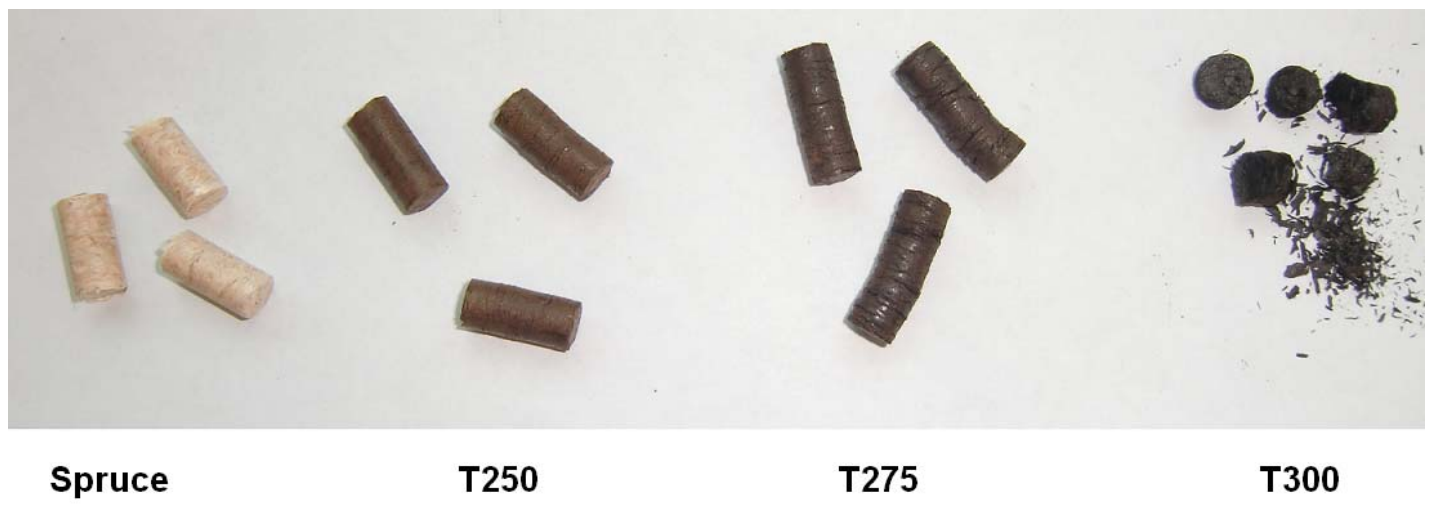

Figure 5. Pellets made from spruce and torrefied spruce. From left to right: Spruce and torrefied spruce at 250,275 an $300{ }^{\circ} \mathrm{C}$.

The pellets were very different in their quality (Figure 5). No pellets could be made from spruce torrefied at $300{ }^{\circ} \mathrm{C}$ and even at $275^{\circ} \mathrm{C}$ the pellets exhibits many defects. The pellet length (after one month storage) increased with an increasing degree of torrefaction from $19.3 \pm 0.3 \mathrm{~mm}$ for spruce pellets to $23.9 \pm 1.1 \mathrm{~mm}$ for spruce torrefied at $250{ }^{\circ} \mathrm{C}$ and $28.5 \pm 1.2 \mathrm{~mm}$ for spruce torrefied at $275^{\circ} \mathrm{C}$. The unit density decreased with an increasing torrefaction temperature from $1090 \pm 19 \mathrm{~kg} \mathrm{~m}^{-3}$ (untreated spruce) to $832 \pm 39 \mathrm{~kg} \mathrm{~m}^{-3}$ for pellets made from spruce torrefied at $250{ }^{\circ} \mathrm{C}$ and to $698 \pm 30 \mathrm{~kg} \mathrm{~m}^{-3}$ for pellets made from material torrefied at $275^{\circ} \mathrm{C}$. This attributes to a spring-back effect and is a sign of poor adhesion between the particles [34]. 


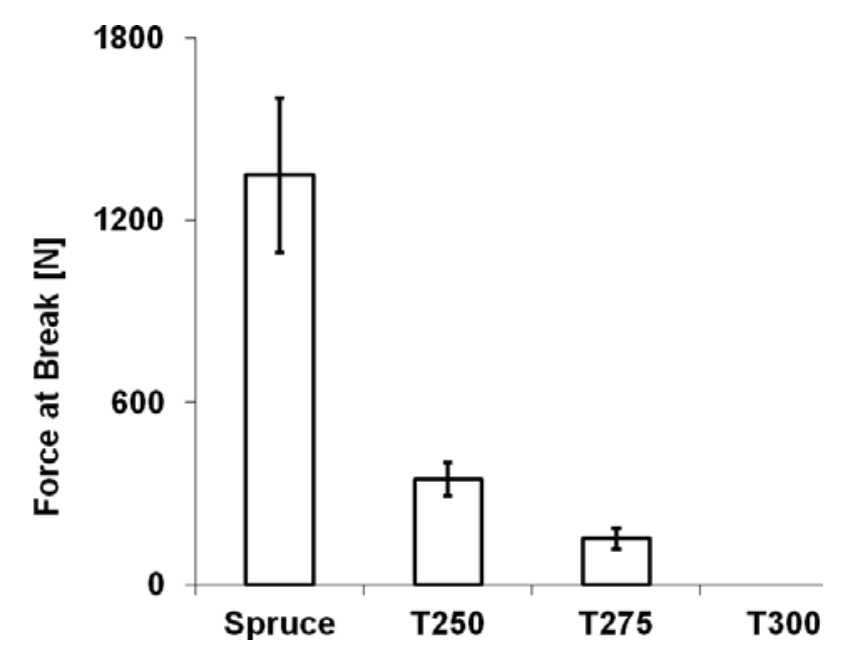

Figure 6. Compression strength of spruce and torrefied spruce pellets.

Figure 6 shows a strong decrease in pellet compression strength as a result of torrefaction. Pellets made from T300 were too weak to be tested. Yildiz et al. [33] have tested the compression strength of spruce that had been heat treated between 130 and $200{ }^{\circ} \mathrm{C}$ for 2 to 10 hours. They found that the compression strength of their samples decreased both with treatment time and temperature and concluded that the strength loss is connected to the degradation of hemicelluloses.

In an earlier work [12], the bonding and failure mechanisms in fuel pellets made from spruce, beech and straw was studied by means of fracture surface analysis using SEM. This method was applied to pellets made from torrefied spruce (Figure 7). 


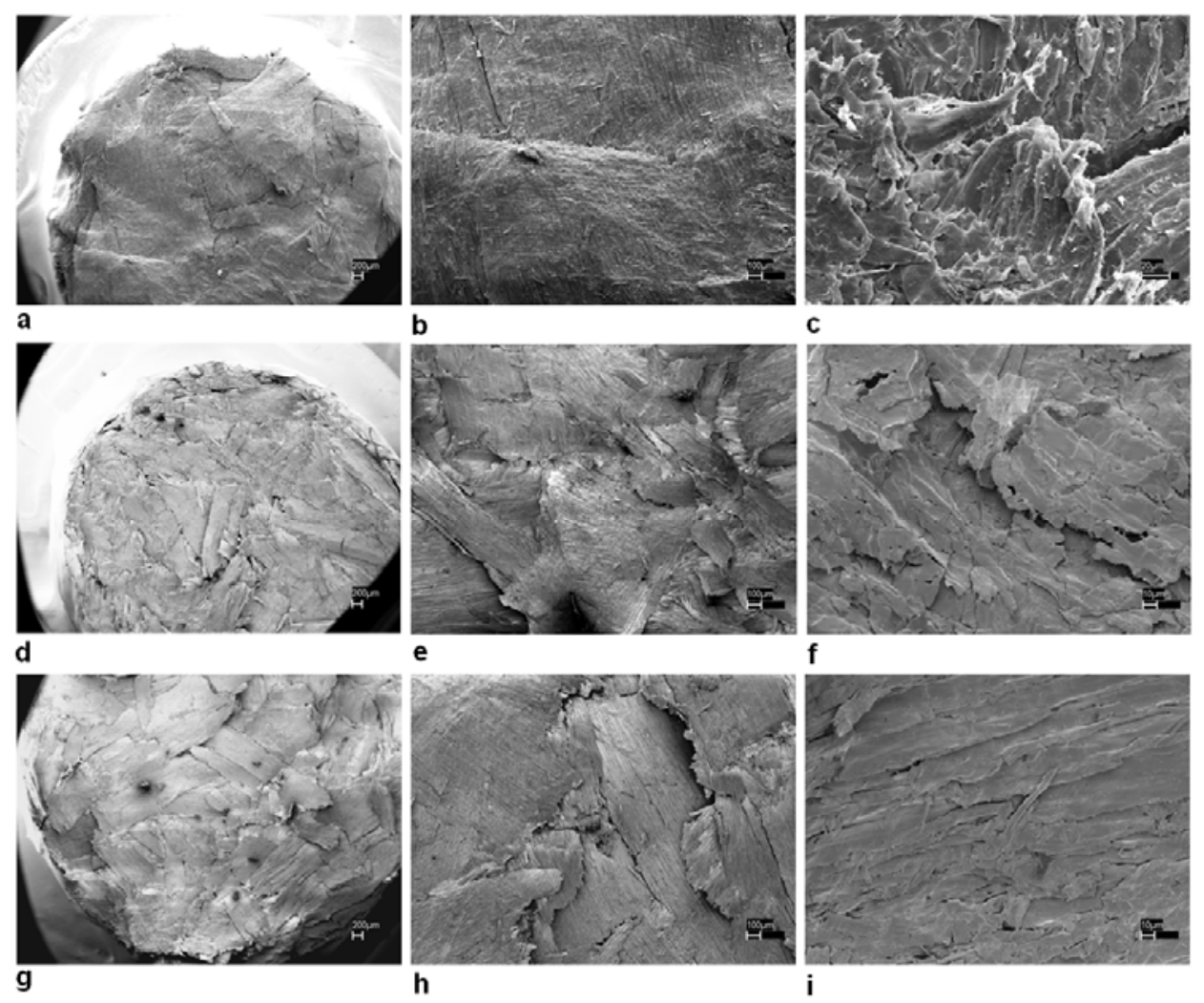

Figure 7. Low, medium, and high magnification, respectively, of a pellet fracture surface for spruce (ac), spruce torrefied at $250{ }^{\circ} \mathrm{C}(d-f)$ and spruce torrefied at $275^{\circ} \mathrm{C}(\mathrm{g}-\mathrm{i})$.

The low and medium magnification images show more inter-particle gaps and voids with increasing torrefaction temperature, indicating poor adhesion between adjacent particles and/or spring back effects $[12,34,35]$. Images taken at higher magnification, (Figure $7 \mathrm{c}$, f and i) provide a deeper insight into the bonding and failure mechanisms of the pellets. The failure surface of spruce pellet (Figure 7c) indicates a cohesive failure with a high energy absorption. Fiber ends and particles are sticking out of the surface and few voids are found. This suggests that lignin and hemicelluloses have exceeded their glass transition temperatures at the pelletization conditions (e.g., moisture content, temperature and pressure), allowing them sufficient mobility to flow into cracks and crevices and establish solid bridges between adjacent particles. The pellets from torrefied wood, T250 (Figure 7f) and T275 (Figure 7i), have flatter 
failure surfaces than those of the spruce pellets, indicating a minimized polymeric flow. The amount of hydrogen binding sites decreases gradually with the torrefaction temperature and the torrefied biomass contains less moisture, thus both hydrogen bonding between polymer chains of adjacent particles and a polymeric flow of the lignin and hemicelluloses (forming solid bridges) can be assumed less likely to occur. According to Rumpf [36] who has studied the binding mechanisms in biomass granules and agglomerates it is likely that Van der Waals forces and fiber interlocking remain as the major forces keeping a pellet together. Since these forces are weak compared to covalent bonds and hydrogen bonding this could be an explanation both for the observed spring back effect (Figure 5) as well as for the low compression strength of pellets made from torrefied spruce (Figure 6).

It is well known that a combination of torrefaction time and temperature determine the degree of polymer degradation and the mechanical properties of heat treated wood $[33,35]$. The mechanical properties of a pellet have been shown to depend on the one hand on the biomass composition i.e. moisture and extractives content and on the other hand on the processing conditions i.e. temperature and pressure $[12,37-40]$. Since hemicelluloses and lignin are both subject to thermal degradation during torrefaction and the amount of available hydrogen bonding sites is reduced, it can be expected that the pellet strength of torrefied pellets is lower compared to pellets made from untreated spruce.

Furthermore, the moisture content of the torrefied wood is lower which results in an increase in the glass transition temperatures of the remaining hemicelluloses and lignin [41]. This may reduce the interdiffusion of the wood polymers between adjacent particles in a pellet and thus the formation of solid bridges between them. The resulting pellets are brittle and less stable than pellets made from untreated wood. To increase the mechanical properties of torrefied biomass pellets it is necessary to establish a better bonding between the particles. One possibility is to add an additive that compensates for the lost bonding sites and ideally binds between the hydrophobic surface of the biomass and remaining polar groups on the wood polymer surface such as short fatty acids or mono glycerids. Another option could be to adjust the torrefaction parameters so that less of the wood polymers are degraded to ensure 
sufficient hydroxyl groups on the wood polymer chains to form strong inter particle bonds. This could be achieved by shorter treatment time, lower torrefaction temperature, different torrefaction medium (e.g. wet torrefaction) or surface increase (e.g. steam explosion conditions).

The development of a combined torrefaction pelletization concept requires that both processes are adjusted to each other. An interesting recent work reports improved mechanical stability and moisture resistance for pellets made from steam exploded Douglas fir [14] performed at temperatures between 200-220 ${ }^{\circ} \mathrm{C}$ for $5-10 \mathrm{~min}$. The water vapor grants a fast heat transfer and the short treatment time and relatively low temperature (compared to our study) preserves sufficient amounts of amorphous polymers that can be plasticized during pelletization and form solid inter-particle bridges.

Future, studies have to investigate the optimal torrefaction conditions to obtain a raw material that both has the beneficial properties of torrefied biomass and also can be pelletized into stable pellets. Furthermore the impact of raw material composition on the torrefaction and pelletizing process has to be investigated.

\section{Conclusions}

The torrefaction of biomass degrades hemicelluloses, cellulose and lignin and removes moisture from the material. Both effects have a strong effect on the pelletizing properties of the biomass. The friction in the press channel of a pellet mill increases, resulting in high pelletizing pressures which increase the energy uptake of the mill and might result in a decrease of capacity and in worst case an overheating (risk of fire) of a blockage of the mills press channels.

Torrefaction breaks down the carbohydrates and therefore the ability to establish hydrogen bonds between polymer chains of adjacent particles can be assumed to be strongly reduced. The lack of 
moisture increases the glass transition temperature of the remaining carbohydrate polymers and restricts the ability of polymeric flow and the establishment of solid bridges between particles. There are several options to overcome this lack of bonding capacity. For example, an additive with a high bonding capacity could be introduced after the torrefaction process that would compensate for the lost hydrogen bonding sites due to torrefaction.

\section{Acknowledgements}

The present study was conducted under the framework of the Danish Energy Agency's EFP project: "Advanced understanding of biomass pelletization" ENS-33033-0227. The authors wish to thank Vattenfall Nordic A/S, DONG Energy A/S and the Danish Energy Agency for project funding. The USDA-Forest Products Laboratory in Madison, Wisconsin is thanked for its hospitality and the provision of laboratory space and equipment for this study. Fred Mat, Dan Yelle and Tom Kuster are thanked for help with chemical analysis, the compression testing and scanning electron microscopy. Charles Frihart is greatly acknowledged for his comments and suggestions when planning this study. Tobias Thomsen is thanked for preparation of the torrefied wood samples and Søren Barsberg for help with the infrared spectra.

\section{References}

[1] Lesage D, Van de Graf T, Westphal K. Global energy governance in a multipolar world. London: Ashgate; 2010. 235pp.

[2] Pentananunt R, Rahman A, Bhattacharya SC. Upgrading of biomass by means of torrefaction. Energy 1990;15(12):1175-9.

[3] Prins MJ, Ptasinski KJ, Janssen FJJG. Torrefaction of wood - Part 1. Weight loss kinetics. J Anal 
Appl Pyrolysis 2006;77(1):28-34.

[4] Arias B, Pevida C, Fermoso J, Plaza MG, Rubiera F, Pis JJ. Influence of torrefaction on the grindability and reactivity of woody biomass. Fuel Process Technol 2008;89(2):169-75.

[5] Pimchuai A, Dutta A, Basu P. Torrefaction of agriculture residue to enhance combustible properties. Energ Fuel 2010;24:4638-45.

[6] Brosse N, El Hage R, Chaouch M, Petrissans M, Dumarcay S, Gerardin P. Investigation of the chemical modifications of beech wood lignin during heat treatment. Polym Degrad Stabil 2010;95(9):1721-26.

[7] Prins MJ, Ptasinski KJ, Janssen F. More efficient biomass gasification via torrefaction. Energy 2006;31(15):3458-70.

[8] Uslu A, Faaij APC, Bergman PCA. Pre-treatment technologies, and their effect on international bioenergy supply chain logistics. Techno-economic evaluation of torrefaction, fast pyrolysis and pelletization. Energy 2008;33(8):1206-23

[9] Blakeslee TR. Fuel free!: Living well without fossil fuels. Seattle: Createspace; 2009. 152pp.

[10] Pirraglia A, Ronalds G, Daniel S. Wood pellets: an expanding market opportunity. Biomass Mag 2010;6:68-75.

[11] Sultana A, Kumar A, Harfield D. Development of agri-pellet production cost and optimum size. Bioresource Technol 2010;101(14):5609-21.

[12] Stelte W, Holm JK, Sanadi AR, Barsberg S, Ahrenfeldt J, Henriksen UB. A study of bonding and failure mechanisms in fuel pellets from different biomass resources. Biomass Bioenerg 2011;35(2):910-8.

[13] Nielsen NPK, Gardner DJ, Poulsen T, Felby C. Importance of temperature, moisture content, and species for the conversion process of wood into fuel pellets. Wood Fiber Sci 2009;41(4):414-25.

[14] Lam PS, Sokhansanj S, Bi X, Lim J, Melin S. Energy input and quality of pellets made from 
steam-exploded douglas fir (pseudotsuga menziesii). Energy Fuels 2011;25(4):1521-8.

[15] Gilbert P, Ryu C, Sharifi V, Swithenbank J. Effect of process parameters on pelletization of herbaceous crops. Fuel 2009;88(8):1491-7.

[16] Davis MW. A rapid modified method for compositional carbohydrate analysis of lignocellulosics by high $\mathrm{pH}$ anion-exchange chromatography with pulsed amperometric detection (HPAEC/PAD). J Wood Chem Technol 1998;18(2):235-52.

[17] Holm JK, Henriksen UB, Hustad JE, Sorensen LH. Toward an understanding of controlling parameters in softwood and hardwood pellets production. Energy Fuel 2006;20(6):2686-94.

[18] Gonzalez-Pena MM, Hale MDC. Colour in thermally modified wood of beech, Norway spruce and Scots pine. Part 1: Colour evolution and colour changes. Holzforschung 2009;63(4):385-93.

[19] Gonzalez-Pena MM, Curling SF, Hale MDC. On the effect of heat on the chemical composition and dimensions of thermally-modified wood. Polym Degrad Stabil 2009;94(12):2184-93.

[20] Gaur S, Reed TB. Thermal data for natural and synthetic materials. New York: Marcel Dekker; 1998.

[21] Yan W, Acharjee TC, Coronella CJ, Vasquez VR. Thermal pretreatment of lignocellulosic biomass. Environ Prog Sustain Energ 2009;28(3):435-40.

[22] Agrawal RK. Kinetics of reactions involved in pyrolysis of cellulose. 1. The 3-reaction model. Can J Chem Eng 1988;66(3):403-12.

[23] Stevanic JS, Salmen L. Characterizing wood polymers in the primary cell wall of Norway spruce (Picea abies (L.) Karst.) using dynamic FT-IR spectroscopy. Cellulose 2008;15(2):285-95.

[24] Fengel D. Influence of water on the valency range in deconvoluted FTIR spectra of cellulose. Holzforschung 1993;47(2):103-8.

[25] Sugiyama J, Persson J, Chanzy H. Combined infrared and electron-diffraction study of the polymorphism of native cellulose. Macromolecules 1991;24(9):2461-66.

[26] Akerholm M, Salmen L. The oriented structure of lignin and its viscoelastic properties studied 
by static and dynamic FT-IR spectroscopy. Holzforschung 2003;57(5):459-65.

[27] Agarwal UP, Ralph SA. FT-Raman spectroscopy of wood: Identifying contributions of lignin and carbohydrate polymers in the spectrum of black spruce (Picea mariana). Appl Spectrosc 1997;51(11):1648-55.

[28] Gierlinger N, Goswami L, Schmidt M, Burgert I, Coutand C, Rogge T, et al. In situ FT-IR microscopic study on enzymatic treatment of poplar wood cross-sections. Biomacromolecules 2008;9(8):2194-201.

[29] Pandey KK. A study of chemical structure of soft and hardwood and wood polymers by FTIR spectroscopy. J Appl Polym Sci 1999;71(12):1969-75.

[30] Berthold J, Desbrieres J, Rinaudo M, Salmen L. Types of adsorbed water in relation to the ionic groups and their counterions for some cellulose derivatives. Polymer 1994;35(26):5729-36.

[31] Holm JK, Henriksen UB, Wand K, Hustad JE, Posselt D. Experimental verification of novel pellet model using a single pelleter unit. Energy Fuel 2007;21(4):2446-9.

[32] Jones L, Milne JL, Ashford D, McQueen-Mason SJ. Cell wall arabinan is essential for guard cell function. P Natl Acad Sci USA 2003;100(20):11783-88.

[33] Yildiz S, Gezer ED, Yildiz UC. Mechanical and chemical behavior of spruce wood modified by heat. Build Environ 2006;41(12):1762-6.

[34] Kaliyan N, Morey RV. Natural binders and solid bridge type binding mechanisms in briquettes and pellets made from corn stover and switchgrass. Bioresource Technol 2010;101(3):1082-90.

[35] Odogherty MJ, Wheeler JA. Compression of straw to high-densities in close cylindrical dies. J Agr Eng Res 1984;29(1):61-72.

[36] Rumpf H. The strength of granules and agglomerates. In: Knepper WA, editor. Agglomeration. New York: John Wiley and Sons; 1962. 379.

[37] Shi JL, Kocaefe D, Zhang J. Mechanical behaviour of quebec wood species heat-treated using thermowood process. Holz Roh Werkst 2007;65(4):255-9. 
[38] Kaliyan N, Morey RV. Factors affecting strength and durability of densified biomass products. Biomass Bioenerg 2009;33(3):337-59.

[39] Larsson SH, Thyrel M, Geladi P, Lestander TA. High quality biofuel pellet production from precompacted low density raw materials. Bioresource Technol 2008;99(15):7176-82.

[40] Nielsen NPK, Gardner DJ, Felby C. Effect of extractives and storage on the pelletizing process of sawdust. Fuel 2010;89(1):94-8.

[41] Stelte W, Clemons C, Holm JK, Ahrenfeldt J, Henriksen UB, Sanadi A. Thermal transitions of the amorphous polymers in wheat straw. Ind Crop Prod 2011;34(1):1053-56. 